\title{
MEDICAL EMERGENCY AND BATTLEFIELD MEDICINE
}

\author{
Pawel Gawlowski ${ }^{1}$, Sandra Pyda ${ }^{2}$, Krzysztof Lukawski ${ }^{3}$, Agnieszka Szarpak ${ }^{4}$ \\ ${ }^{1}$ Department of Emergency Medical Service, Wroclaw Medical University, Poland \\ ${ }^{2}$ Polish Society of Disaster Medicine, Warsaw, Poland \\ ${ }^{3}$ University Clinical Hospital in Wroclaw, Poland \\ ${ }^{4}$ Lazarski University, Warsaw, Poland
}

\begin{abstract}
A victim in a life-threatening situation is a big challenge for rescue services around the world. Especially in a situation where assistance is to be provided in conditions that also threaten rescuers. Such an event may occur, for example, in the conditions of the battlefield. In order to provide effective assistance, separate rescue systems had to be implemented, which on the one hand included effective assistance to the victim, and on the other, they adapted it to the battlefield. These systems allow limited exposure to the risk of health or life-threatening situations to the rescuers. The paramedic operating in the emergency medical system operates in the safe zone with the equipment in emergency backpacks, along with an ambulance and entities supporting the State Medical Rescue system. The victim is to receive full assistance according to current standards. The patient is to have all the tests done to confirm or rule out life-threatening injuries. Evacuation to the hospital takes place, if the situation requires, using equipment to fully immobilize the spine. Acting in combat conditions, a paramedic in a dangerous zone provides assistance to an injured person in the field of authorship or performs only simple activities to protect the basic life functions of the victim. It is only in a potentially safe zone that he uses emergency equipment stored in a rescue pack or a personal first aid kit. Evacuation of the victim takes place on a stretcher, which does not fully protect the victim with a spinal injury.
\end{abstract}

KEY WORDS: emergency medical services, tactical medicine, paramedic, evacuation, rescue equipment

Disaster Emerg Med J 2019; 4(1): 18-28

\section{INTRODUCTION}

Providing first aid and conducting medical rescue operations is an indispensable element related to the work of a paramedic. In the 20th century, both the algorithms describing rescue operations and the equipment used to provide help to the injured changed very intensively. This was related both to the intensive development of technology and the large-scale military operations in various parts of the world and the development of terrorism. Since ancient times, when the beginning of the development of emergency medical services arose, it was necessary to use the equipment also for military purposes. Conducting war activities led to the creation of the first field first aid points and the development of algorithms that can be used on the battlefield. The first attempts to create guidelines on the battlefield were based mainly on the assessment of the number of soldiers who were helped in the event of serious injuries and on the possibilities of providing this assistance in potentially safe conditions for the rescuer. They are dated to the period of Napoleonic wars. Medical rescue operations performed by a paramedic in a civilian context are based primarily on 
the priority of operation in a safe or potentially dangerous place but protected by services statutorily appointed to perform the above tasks. The difference in civil and military rescue is that they result mainly from the level of safety of rescue operations performed with the injured, and with the availability of equipment, with its specific selection and modification, depending on the field of operation. An important element is also the medical facilities, where the victim can receive help in the full range. The patient evacuation also depends on the diversity of the area and the possibility of safe evacuation by land or air. Another component that differentiates tactical and civilian activities is the type of injuries. In the case of a tactical rescue, the overwhelming majority relate to victims with multi-organ trauma, combined with massive haemorrhages. This is related to the use of fast-acting hemostatic agents and life-stabilizing equipment in the above-mentioned situation. The beginnings of tactical and civil rescue were based on the pre-hospital treatment of paramedics. Their limited medical education and the scope of authorization to perform rescue operations meant that the amount of rescue equipment was very limited. The creation of the educational direction of paramedics also increased the level of knowledge and skills in the field of performing medical emergency procedures. It was also connected with the introduction of more and more advanced rescue equipment and medical procedures to pre-hospital treatment [1]. Systematic tactical rescue operations were also started. The principle of operation has been introduced based on the created algorithms, so that during operation, in particular in the danger zone, e.g. with patients who have suffered severe injuries, carry out all necessary activities with the victim in a standardized manner, safely evacuating the patient to the safe zone [2]. In Poland, the range of medical rescuers' competence was significantly expanded by the Act on State Emergency Medical Services in 2017.

The regulations contained therein allow the medical rescuer to perform medical rescue operations in units subordinated to the Minister of National Defense and the Ministry of Interior and Administration. The changes described above, the ever-changing competence of paramedics, and the development of new technologies used in emergency medical services, create the desirability of comparing civil and military rescue systems and citing life-saving procedures performed by paramedics in a safe and dangerous zone.

\section{PROCEDURE WITH TRAUMA PATIENT}

\section{Emergency medical services}

One of the main trips of medical emergency teams is car accidents. As a result, there are many injuries sustained by a victim. They can be light scratches, as well as multi-organ injuries. Both the first and the latter should follow specific patterns. Upon arrival at the scene, paramedics wait until the fire brigade officers or other authorized personnel make access to the victim or evacuate him from the danger zone. Then they perform the first stages of the patient's examination. During the preliminary examination of the victim, follow the ABCDE scheme, where [3]:

- A (airways) means airway patency and the level of awareness of the victim,

- B (breathing) means breath,

- C (circulation) means circulation,

- D (disability) means the assessment of disturbances in consciousness,

- E (exposure) exposure.

At the very beginning, the general impression that the patient makes should be assessed, as well as the mechanism of the injury which they have experienced in order to direct further investigation. Then one starts with the stabilization of the head. For this purpose, one of the rescuers should grab the victim's head, adjusting himself to allow the other rescuer to take over the stabilization and focus on stopping the patient's life-threatening haemorrhage and conducting the examination. In the case of a local injury, it will be a simple local examination, in the case of more serious injuries, a preliminary trauma examination should be performed [4].

After taking over the stabilization of the injured person's head, one should open his or her airways by moving their mandible forward. The first rescuer evaluates the patient's awareness of the AVPU scale and then evaluates the breath, which should last 10 seconds. If the patient has a respiratory rate of less than 10/minute, the rescuer will start mechanical ventilation using a self-inflating bag. In case when the breath is $>24$, assisted breathing should be implemented, based on active oxygen therapy, injecting air at the moment of the patient's breathing every fifth breath.

After assessing the breath and possible implementation of oxygen therapy, one should start a blood circulation test. At this stage, the rescuer performing the test assesses the frequency and elasticity of the patient's pulse. The test is performed on 
the carotid and radial artery. One should allocate 10 seconds for this action. If the heart rate is accelerated $>100 \mathrm{bpm}$ is or is absent in the peripheral arteries, the circulatory shock should be suspected. At this stage, the capillary refill time is also evaluated, which also confirms or precludes centralization of circulation.

After assessing the circulation, the team should be able to assess the state of consciousness of the victim on the Glasgow scale. Next, they shall proceed to a quick physical examination. After identifying the trauma by the rescuer, the third rescuer, if present, and if the situation allows, can proceed to treati injuries to shorten the time to evacuate. If the rescue team consists of two persons, the wound is addressed only after the end of the examination, because the examination can be stopped only in the case of a sudden cardiac arrest in the victim or when the situation becomes dangerous [5]. When examining each area of the body, pay attention to injuries such as:

- Lacerations,

- Tenderness,

- abrasions,

- Penetration,

- Deformation,

- Burns,

- Bruises,

- Crackles,

- Swelling,

- Instability.

The examination should start from the head. Particular attention should be paid to wounds in this area and visible facial bone fractures. During palpation, however, one should look for indentations, crepitus and areas where there is tenderness to palpation. Attention should also be paid to the area of eye sockets and behind the ears of the victim, wherein the case of a fracture of the skull base, characteristic hematomas (eyelid hematoma and Battle's sign) arise. In addition, blood or cerebrospinal fluid may leak from the ears and nose.

After examination of the head, the neck of the victim should be examined. One would pay special attention to haemorrhage, filling of the jugular veins (whether they are collapsed, overfilled or physiologically filled). Attention should also be paid to the positioning of the cervical vertebrae, the arrangement of the trachea, or the displacement of which may indicate pulmonary embolism. One cannot forget to pay attention to the presence of subcutaneous cracks, which prove subcutaneous emphysema.

The next part of the body to be examined is the chest. Here one looks again for haemorrhages, fractures, crepitus, tenderness. The most dangerous injuries are penetrating wounds. If present, a valve dressing is necessary. The chest should also be auscultated and taped to identify or exclude the resonant pneumothorax. In a situation where it is present, it should be decompressed by puncturing the chest in the midclavicular line in the third intercostal space, leading the needle on the upper edge of the rib IV.

The next step is to examine the abdomen. Again, one should pay attention to visible wounds and haemorrhages. In the palpation exam, divide the abdomen into four quadrants, assess the peritoneal symptoms, as well as check that the abdomen is flat, if the patient is conscious when examining the abdomen, ask about the nature of pain both during pressure and relieving pressure. In the case of abdominal open wounds, attention should also be paid to the presence of erectile exudates. During further examination, be careful that these do not arise as a result of the pressure of the abdominal cavity.

After examining the abdomen, the exam proceeds lower to the examination of the pelvis. During the exam, attention is paid to crackling, instability, the presence of bony fragments, deformation and open wounds. In addition, the genitals are important to note because urinary incontinence and priapism may indicate spinal cord injury. The pelvis is examined by evaluating the shape and placement of its bones. The next step is gentle compressions of the spines in the centre. The last manoeuvre is gentle compression of the pubic symphysis with the base of the hand. If the pelvis turns out to be unstable in any of the stages of the pelvic examination, it should be stopped in order not to aggravate the injury. In addition, the victim should not be turned on its side to examine the back or during transportation to the stretcher.

Once the pelvic condition is known, one can begin to assess the extremities. In the first place, the lower limbs are examined. As in previous cases, one looks for bleeds, wounds, deformities, fractures, as well as joint sprains and amputations. It starts from the femur toward the bottom ending at the feet. First, the continuity and contour of the limb are assessed, then with a delicate lever it is checked whether any of the long bones are broken. In the 
case of lower limbs, first the femur is assessed, then the bones of the lower leg. In the case of upper limbs, first the humerus, then the forearm bones are assessed. Each limb should also be examined under the PMS account (pulse, motor skills, sensor). The pulse on the lower limbs is sought on the femoral, popliteal and dorsal femoral arteries. On the upper limbs the brachial and radial artery are palpated.

The last stage of the examination is the assessment of the victim's back. To do this, place the patient on the side if possible, or use a landing net. Before the examination of the back, a stretcher or an orthopaedic board should be prepared for transferring the victim after the assessment. During the back examination, the vertebral column should be assessed. One should look for wounds, haemorrhages, and foreign bodies. After examining the back and possible supply of wounds, the patient should be placed on a stretcher.

During the examination, when the victim is conscious, an interview should be collected in accordance with the acronym SAMPLE [6], where:

- $\mathrm{S}$ (signs and symptoms) - symptoms, i.e. what the victim is experiencing at the moment;

- A (allergies) - allergies, especially for medicines,

- $M$ (medications) - medicines taken by the victim long-term and whether he or she took them, in what doses, and when;

- P (past medical history) - patient's past history; women should also be asked about the possibility of pregnancy;

- L (last meal) — when the patient has recently had a meal and if it was abundant: this is of key importance for anesthesiologists in the event of a possible surgery after being brought to the hospital;

- E (events) - events preceding the event, to determine what led to the situation and what is the consequence of it.

It is important to ask all the questions in the interview and to remember all the patient's answers.

Once the the additional information are provided from the victim, one should immediately proceed to further actions to save the victim's life, such as the implementation of fluid therapy, pharmacotherapy and the use of appropriate dressings.

Intravenous access should be performed for each victim, preferably two independent punctures. It is a good idea to consider cannulation of the external jugular vein for rapid supply of fluids and medications.

\section{Battlefield Medicine}

Help on the battlefield is radically different from the civilian world. To help the injured, rescuers do not have a huge amount of equipment. Everything that can help to save the wounded must be in their backpack. It can be common for the fire to open on both sides of the front during the rescue. An additional factor hindering the rescue is the constant exchange of fire on the battlefield, however, the rescue is a priority. Time is key in this situation. In order to minimize the risk of injury to the rescuer, as well as to shorten the period between the occurrence of an injury in the victim and the start of providing help, the rescue is divided into three phases.

The first, and at the same time the most important, is the medical treatment under fire (called Care Under Fire). In this phase, while taking care of one's own safety, the victim should be managed in such a way that he or she can help themselves if possible. It is possible only in a situation when the victim is conscious and able to perform the activities ordered to him by the medic. In any other case, the haemorrhage of the injured should be stopped and the victim evacuated as soon as possible to the relatively safe place while beginning the assessment [7].

From now on one proceeds to the next phase, which is the tactical medical care (Tactical Field Care). This phase should begin with disarming the victim because if in shock and wanting to defend himself, a victim may try to attack us. Then one can start to examine the patient. If the situation permits, it should be tested in accordance with the ITLS guidelines. In a situation where there is no time to conduct a full examination, it should proceed in accordance with the MARCHE [8] protocol, where:

- M (massive bleeding) - detection and suppression of massive haemorrhages that threaten the life of the victim,

- A (airways) - assessment of airway patency,

- R (respiration) - breath assessment,

- C (circulation) - assessment of circulation,

- H (head, hypothermia) - assessment of the head of the injured and prevention of cooling down of the body,

- E (everything else) - means all other activities that should be done to save the life of the victim. When assessing the condition of the victim, first of all, one needs to take care of one's own safety. To provide for oneself and the patient, one must evacuate the victim from the fire line to a shielded place. The next thing to look out for is the mech- 
anism of injury. Thanks to their knowledge, the rescuers can predict the patient's potential injuries and focus on the examination. When assessing the mechanism of injury, particular attention should be paid to the force and the time that affected the body of the victim during the injury and also the body part that was damaged.

The next step in the exam is to assess the overall impression of the victim. It is necessary to pay attention to the body position, age, sex, approximate body weight, as well as visible injuries with particular regard to haemorrhages. One of the causes of avoidable deaths is massive limb haemorrhage. On the battlefield they are inevitable, especially in the case of traumatic amputation. They should be stopped quickly. The most effective in this case is the tourniquet, the so-called tactical stasis. If the victim is conscious, the soldier should apply it himself immediately after suffering the injury [9].

After controlling the haemorrhage, the basic vital parameters should be assessed immediately. The first step is to assess the patency of the airways and, if necessary, restore them. If the patient's airways are blocked, they need to be cleared. They are carried out adequately to the condition of the victim: by tilting their head back, or by pulling their mandible forward.

When the patient's respiratory tract is already clear, one immediately moves on to the next step, which is the breath assessment. This assessment is carried out by the rescuer for 10 seconds. If the injured person performs one breath or does not perform one at a time, ventilation using a self-inflating bag is applied.

To maintain patency of the patient's airways, use the nasopharyngeal tube that each soldier should have in their first aid kit. If its use does not bring the expected results, it is necessary to consider using supraglottic devices such as LMA or LT. Under tactical conditions, intubation is a difficult manoeuvre to perform due to time constraints and often a very stressful situation. An alternative solution is a tracheotomy and cricothyrotomy. These are traumatic procedures and are performed only in situations where the remaining possibilities to maintain airway patency are impossible [9].

After the breath assessment, it's time to assess the circulation. This should be done by examining the pulse on the carotid and radial artery, for which one also should devote 10 seconds, as well as assessing the appearance of the skin. Heart rate should be appropriately tense, elastic, and palpable both on the carotid and radial artery. It should also not exceed 100 beats per minute. At this stage, all wounds of the victim should be visible.

After completing the assessment of basic vital functions of the patient, one can go to the next stage, which is to examine the head and to prevent the patient from cooling down. Head injuries are the most dangerous of all possible on the battlefield as well as in civil conditions. The main task in dealing with head injuries is to prevent secondary injuries.

Chest injuries make up about $10 \%$ of all body injuries on the battlefield. Due to the organs, heart, lungs and the proximity of parenchymal organs, trauma is always a life-threatening condition. With the development of technology, each soldier's personal equipment includes a ballistic vest designed to minimize the damage, but it is unlikely to always reduce the damage to none. During the examination of the victim, the rescuer must reveal the patient's torso by pulling the vest to reveal possible injuries and to create access to the next steps. When testing the chest, follow the ABCDE diagram. When assessing the breath, one can ask the injured person to, for example, count up to ten. Issues with the execution of this command will be indicative of increased respiratory effort. Then the rescuer should assess the quantity and quality of the patient's breaths, check the saturation and look at the chest. Then, according to the acronym TWELVE [10] where:

- $T$ (trachea) means the location of the trachea,

- W means wounds,

- E (emphysema) means subcutaneous emphysema,

- L (laryngeal injury) means laryngeal injury,

- $V$ (veins distended) means jugular vein tension,

- E (every time) means one needs to check the chest every time.

The most common chest injury on the battlefield is open pneumothorax. It arises as a result of a gunshot wound or shrapnel detachment. A result of this injury is a hole in the chest, which allows air entry, therefore, compression on the lung, not allowing it to expand during inhalation. To prevent this condition from worsening, this wound should be sealed using an occlusive dressing by applying a piece of film and carefully wrapping it around the wound with a wide band. Another method is the use of valve dressings. If despite the use of an occlusive dressing the symptoms of respiratory failure increase, one should proceed as in the case of a closed pneumothorax and decompress by puncturing the 
chest in the midclavicular line on the upper edge IV of the rib on the side of the injury.

Abdominal injuries on the battlefield are mainly penetrating injuries caused by debris resulting from explosions. They are much less likely to be blunt injuries or gunshot wounds. Penetrating damage causes damage to more than one organ, and the extent of damage is caused by the force that a fragment, a bullet, or a sharp tool has impacted on the victim. The damage from explosions is more complicated.

They should be divided into four groups. Primary injuries are caused by a shock wave resulting from an explosion. Secondary injuries are wounds resulting from the body contacting with the fragments formed during the explosion. Tertiary injuries are stemmed from secondary injuries resulting from the body being hit by the ground, walls, or other hard objects. Quaternary injuries are burn wounds created as a result of skin contact with high temperature generated during an explosion. When examining the stomach, one should divide it into four quadrants. The upper right quadrant includes the liver, gallbladder and part of the colon. The upper left quadrant includes the stomach, spleen, pancreas and part of the colon. In the right lower quadrant there is an appendix, small intestines and part of the bladder. And the lower left quadrant includes the sigmoid, small intestine and urinary bladder. During the examination, each of the separated abdominal zones is squeezed. Soreness in a particular field indicates a specific organ injury. During the examination, attention should be paid to bruising, firmness, muscle tension, pain and its nature, haemorrhage and emaciation. In case of haemorrhage, pressure dressings should be applied in place of bleeding, if there is an eventration, the dressing should be moistened with physiological saline and the whole abdomen should be wrapped without pushing the intestines back into the abdomen.

Intravenous access should be performed only if the patient is in hypovolemic shock and requires immediate fluid therapy. It is recommended to perform a puncture in the external jugular vein because the peripheral veins in the shock are salvaged. This injection should be performed with the patient lying down to minimize the risk of pneumothorax. In addition, if the patient has suffered a chest injury, IV access should be done on the side of the injury to minimize the likelihood of bilateral pneumonia. Intraosseous puncture is an alternative to cannulation of veins. In tactical conditions, there is often no time to try to set up a venipuncture, therefore intraosseous access is more desirable because of its ease and speed of execution. In the Polish Army, the FAST1 system is most commonly used, because the sternum in which it is inserted is a bone that is easy to locate. It is also protected by a bulletproof vest, which makes the damage to the bone unlikely, in contrast to limb bones in which it is assumed injections using BIG or EZ IO sets.

The last phase of helping a victim on the battlefield is a tactical evacuation care. To evacuate from the battlefield, the best solution is to use a helicopter in the MedEvac [11] protocol. This is a nine-line report that should be given in a specific order on a fixed radio band to determine the location and necessary forces and resources necessary to evacuate the victim from the scene of the incident. Then, the MIST report is given, describing the condition of the victim.

\section{EQUIPMENT USED BY THE VACUUM CLEANERS}

\section{Emergency Medical Services}

Equipment used in emergency services can be divided due to the stages of providing assistance to the victim. The first at the place of the incident are witnesses of the event or participants of the accident. Usually, they do not have any medical equipment, or they have simple car first-aid kits in which there are plasters, bandages and gauzes.

The fire brigades of both the Volunteer Fire Brigades and the State Fire Service are often out of the services authorized to provide assistance to the victims. The clutches of these formations are equipped with the so-called PSP R1 [12] set (Fig. 1), which includes:

- a set of oropharyngeal tubes,

- a set of laryngeal tubes or laryngeal masks,

- CO2 detectors in the expired air,

- a mechanical bag,

- self-expanding bags (for children and adults),

- antibacterial filters,

- oxygen cylinder with reducer,

- a set of orthopaedic collars,

- personal dressings,

- gas compressions,

- gauze bandages,

- knitted headbands,

- elastic bands, 


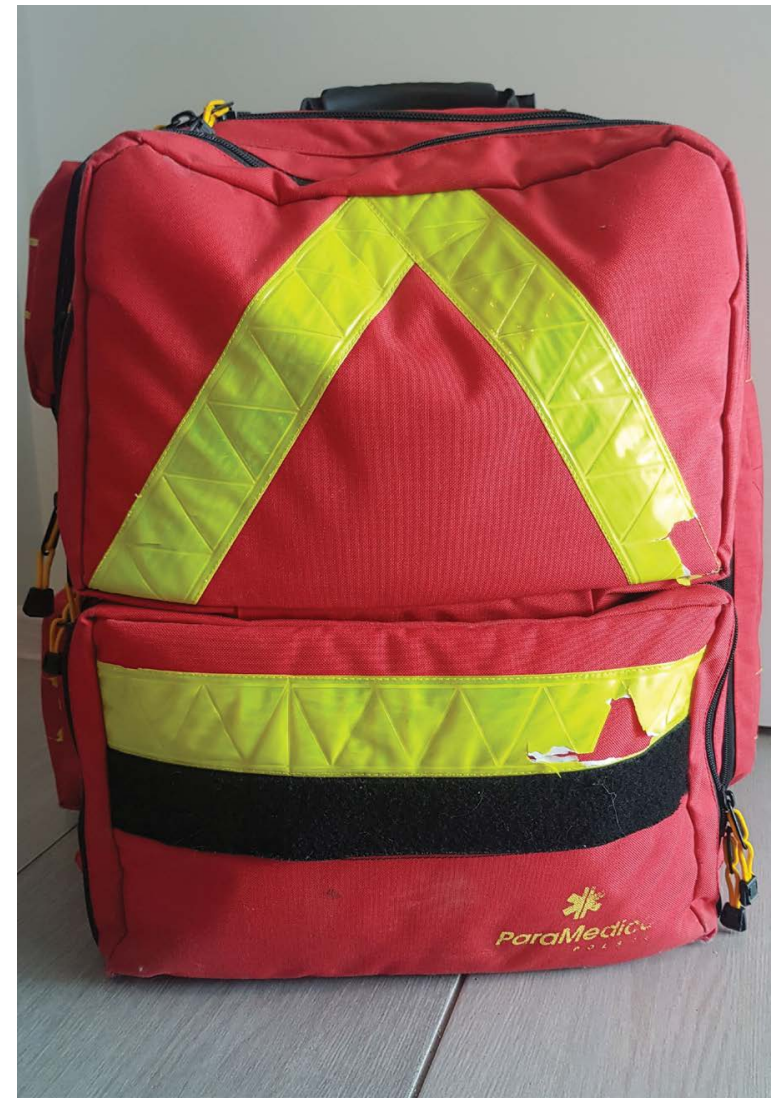

FIGURE 1. Equipment for PSP R1 bag

- triangular shawls,

- dressing netting,

- patches with a dressing,

- patches without dressing,

- hydrogel dressings,

- valve dressings,

- zippers,

- physiological saline for washing wounds,

- bags for amputated body parts,

- bags to cover the corpses,

- Kramer rail,

- orthopaedic board.

The next people providing help for the incident are medical rescuers from the emergency medical team. they have specialized equipment to save human life and health. Ambulance personnel have the equipment that firefighters have but in much larger quantities. In addition, they have equipment such as:

- intubation kit,

- a defibrillator cardiac monitor with

- a respirator,

- electric mammal,

- infusion pump,

- a set of 48 medicines,
- catheters,

- fluids ( $0.9 \% \mathrm{NaCl}, \mathrm{PWE}$, Ringer's bulb),

- catheters and plasters for them,

- devices for fluid transfusion,

- sets for fluid therapy under increased pressure,

- a blood pressure monitor and stethoscope,

- a pulse oximeter,

- vacuum stretcher,

- landing field litter,

- a stretcher,

- self-propelled stretcher,

- transport chair,

- KED vest.

\section{Medicine battlefield}

The basic equipment used in tactical medicine is an individual medical package (Fig. 2), which every soldier has. This package includes the measures necessary to protect injuries directly threatening the life of a soldier on the battlefield. The set includes:

- personal dressing,

- hemostatic dressing,

- filling gauze,

- a cable tie,

- dressing for chest penetration wounds,

- a syringe with morphine,

- nasopharyngeal tube with water gel,

- scissors used to cut the victim's uniform.

The content of this package is used by every soldier rescuing the injured colleague in the first phase of pro-

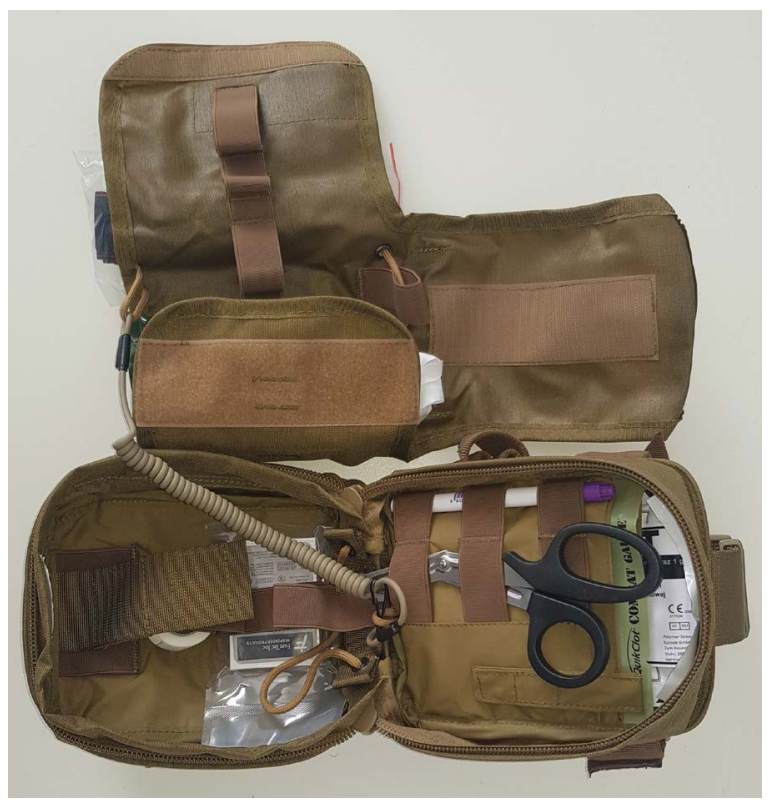

FIGURE 2. Individual medical package of a soldier of the Polish Army 


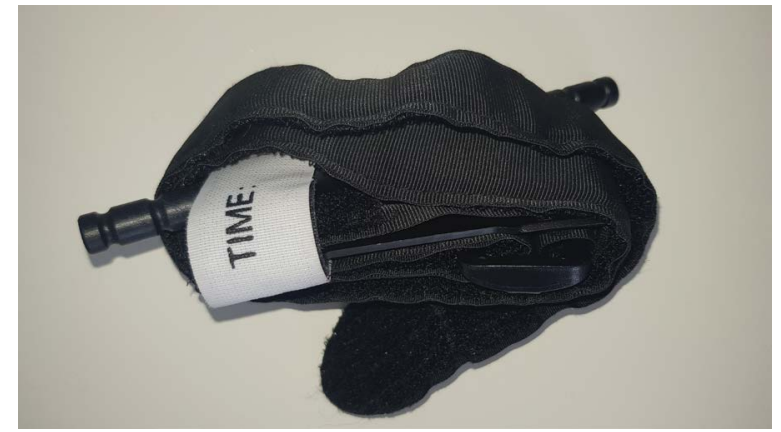

FIGURE 3. Cable tie

viding help. The equipment from the medical package of the injured soldier is used in this situation [13].

Cable tie - the so-called tactical stasis (Fig. 3), it has the task of clamping arteries, which stops the bleeding. Stasis should be placed $5-7 \mathrm{~cm}$ above the wound site, or in accordance with the high \& tight principle at the base of the limb. After inserting the band, one should write the time on which it was used, because it cannot be kept clamped for more than 2 hours.

Filling gauze - used for packing deep wounds from limbs, or in injuries to parts of the body above which stasis cannot be achieved. There are several types of wound filling gas on the market. They all have the task to fill the wound, absorb extraneous blood, squeeze the blood vessels and stop the bleeding. They are often soaked in addition with a hemostatic agent that accelerates the clotting process.

Individual dressings - consisting of an elastic bandage and an absorbent tampon together with it. In some, there is also an additional portable compress, thanks to which it is possible to provide one dressing with the inlet and outlet wounds of the shot or to increase the surface or volume of the absorbent dressing in case of a large wound.

Israeli dressing - is a variation of the individual dressing, has additional plastic elements to help tighten the bandage more firmly. The first element is used to change the direction of bandaging and pressing the compress absorbing the wound. The second one is at the end of the bandage, it is used to hook the end of the bandage to the previous tubing. One can also make a stump from it, by tightening it a few turns earlier.

OLAES dressing - is another variation of the individual dressing (Fig. 4), it is equipped with a plastic element in the shape of a lens, designed to tighten the absorbent dressing in place of wounds, it can

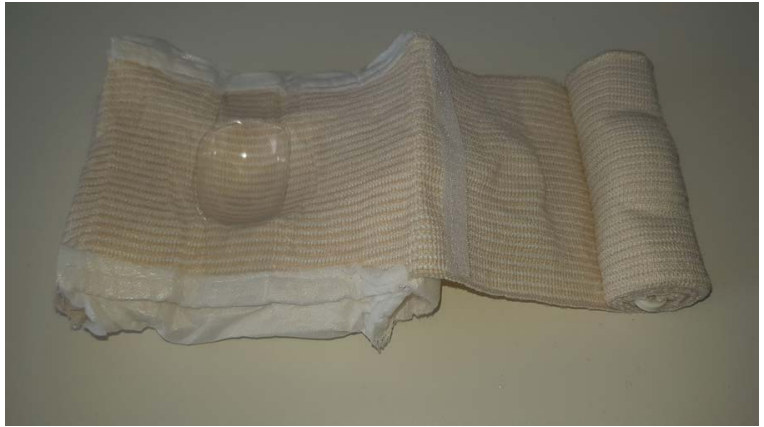

FIGURE 4. OLAES dressing

also be used as an eye dressing. In addition, the absorbent part consists of gauze for wound packaging. There is also a piece of foil hidden in it for the occlusion dressing, and additionally, a dozen or so centimetres on the bandage is velcro, aimed at preventing an accidental situation of the rescuer's hand falling out. At the end of the bandage there is a plastic element to attach it to the previous layers to terminate the bandaging, or to make several turns to tighten the bandages.

Valve dressing - it is placed on chest penetrating wounds. The most common are the ACS dressing (Asherman Chest Seal), which has a rubber valve to prevent air from being sucked into the wound. The new generation dressing is BCS (Bolin Chest Seal), which has three independent valves that allow the air to escape from the wound but prevent it from getting inside.

Nasopharyngeal tube - the simplest device to maintain airway patency. It is individually matched to the light of the right nose of the soldier who has it in his medical package.

A morphine auto-syringe - every soldier of the Polish Army has one dose of $20 \mathrm{mg}$ of morphine sulphate, which the soldier is able to give himself in the case of severe pain occurring, for example, in the case of limb amputation.

In addition, a paramedic who is a member of the task department has a backpack (Fig. 5), in which he has a larger number of dressings, medical equipment and medications, thanks to which he can secure the rest of injuries in subsequent phases of assistance. The equipment of this backpack includes:

- triangular shawls,

- gauze bandages,

- filling gases,

- sterile compresses,

- elastic bands,

- hemostatic dressings, 


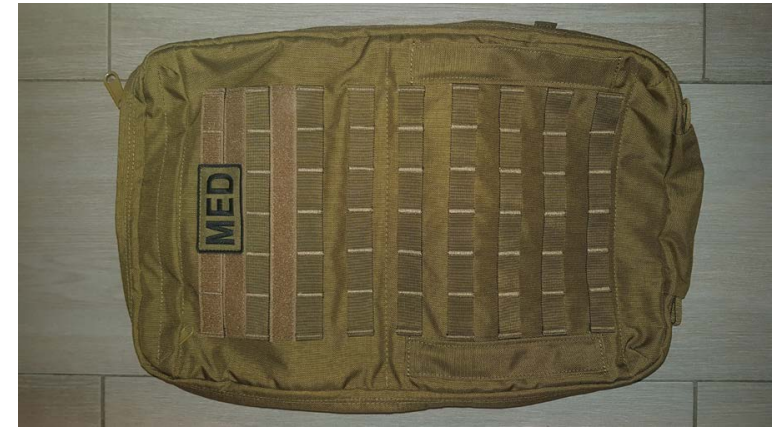

FIGURE 5. Exterior of the Polish Army paramedic's backpack

- abdominal dressing,

- individual dressings,

- wound dressings penetrating the chest,

- patches without dressing,

- patch with a dressing,

- dressing net,

- zippers,

- a decompression needle for the pneumothorax,

- laryngoscope,

- intubation tubes,

- laryngeal tubes,

- nasopharyngeal tubes,

- oropharyngeal tubes,

- hand-held mammal,

- self-inflating bag,

- horse breeding kit,

- hydrogel dressings,

- an orthopedic collar,

- SAM SPLINT type rails,

- disinfection swabs,

- needles for injection and drug administration,

- syringes,

- catheters,

- veneer foil,

- flexible stasis,

- fluid handling kits,

- a set for intraosseous entry,

- fluids (PWE, $0.9 \% \mathrm{NaCl}$, Ringer's solution),

- a blood pressure monitor,

- stethoscope,

- a pulse oximeter,

- gloves,

- ocular dressings,

- NRC and Blizzard blankets,

- flashlight,

- surgical kit for sewing,

- scissors,

- a kit for evacuating the victim (foxtrot litter),

- a set of colored chemical lights

\section{TRANSPORT OF INDEPENDENT PEOPLE}

\section{Emergency Medical Services}

During rescue operations, the best means to evacuate a dangerous place is the orthopaedic board. With its help, the victim is moved to a safe zone where he or she is transferred to an ambulance stretcher which will be transported to the hospital. Patients with injuries are best transported in a vacuum stretcher, as they ensure the stabilization of the entire body of the victim. In the case of an injured person with multi-organ injury, the best solution is air transport. For this purpose, the emergency medical team can summon the HEMS team of the Aviation Emergency Service to transport the patient to the nearest trauma centre [14]. This solution significantly shortens the patient's transport time, which increases the chances of survival of the injured in a critical condition.

\section{Medicine battlefield}

First, the victim is evacuated by another soldier without using any specialized equipment. This is to remove the victim from a live fire as soon as possible into a potentially safer place. Then, after all rescue operations have been carried out, the injured person is evacuated on a stretcher to the zone from which he will be taken by a special vehicle adapted to transport the injured or a helicopter. While the rescuer helps the victim, one of the soldiers in the ward reports MedEvac [15] on the radio. Its purpose is to call for a victim to be transported to a field hospital. This report must contain individual information in a specific order [16].

1) The coordinates of the place where the victim is located, i.e. the place where the helicopter landing pad will be designated, should be remembered to erroneously give the coordinates of the current stay or the place of the event.

2) Information on the radio frequency on which monitoring will be carried out by the branch waiting with the injured for transport in order to establish radio communication with the medical helicopter. A calling code and other information necessary to establish communication with the branch is also given.

3) A Number of patients with a specific evacuation priority. The injured persons who should be transported to the field hospital within two hours are specified in the MedEvac protocol as $A$, to this group we include: 
- significant wounds caused by IEDs,

- gunshot wounds or shards in the chest, abdomen or pelvis,

- problems with airway obstruction,

- breathing difficulty,

- the wounded is unconscious,

- spinal injuries or suspicion,

- hypovolemic shock,

- bleeding is difficult to control,

- moderate or serious traumatic brain injury,

- burns $>20 \%$ of the body surface.

Injured persons who can be transported up to four hours are referred to as $B$, here persons qualify for:

- there is an open limb fracture (insulated) with controlled bleeding,

- a cable tie has been installed,

- there have been mechanical eye injury,

- soft tissues are seriously damaged without significant bleeding,

- limb injuries have occurred without a peripheral pulse,

- $\quad 10-20 \%$ of the body surface has been burned.

People who require routine transport and their lives are not in danger are identified as group $C$. They will be evacuated in time up to twenty-four hours, and in this group there will be anyone who has:

- a slight concussion,

- gunshot wound captured without a tourniquet with controlled bleeding,

- slight damage to soft tissue,

- closed fractures with perceptible peripheral pulses,

- body burns $<10 \%$ of the body surface.

It should be noted here that the time provided is the time from the occurrence of the injury, not MedEvac's call, as this is usually called for 15-30 minutes after the injury.

4) Specialized equipment will be necessary to carry out the evacuation and transport of the victim:

- A - no requirement to have such equipment,

- B - one will need a winch for evacuation because the helicopter will not be able to land,

- C - extraction equipment necessary to evacuate the victim,

- $D$ - a ventilator to support the patient's replacement breath.

5) The number of patients due to the mode of transport:

- $L$ - is the number of patients that need to be transported lying,
- A - means sitting patients.

6) Safety in the landing zone. Shortcuts are used to speed up correspondence:

- N - means no opponent in the zone,

- P - the possibility of the appearance of the enemy,

- E - means that there is an opponent in the landing zone,

- X - means fire contact.

7) The way of marking the helicopter landing pad:

- A - panel,

- B - pyrotechnics,

- C - smoke race,

- D - no markings,

- E - another way of marking the landing pad.

Thanks to this information, the pilot knows what to look for in order to find the exact place of landing.

8) Who is the victim:

- A - a coalition soldier,

- B - a civilian person of the coalition,

- C - a soldier from outside the coalition,

- D - a civilian from outside the coalition,

- E - prisoner or person of tactical importance.

During transport $\mathrm{E}$ on the helicopter deck there must be an additional person who will interrogate the prisoner during transport and medical services. An escort of armored helicopters will also be necessary.

9) Information on possible contamination of the area:

- N - means nuclear contamination,

- B - means biological contamination,

- C - means chemical contamination,

- N/A - means no contamination at the place of taking the victim.

It should also be mentioned here about possible obstacles in the field, tips for locating the victim, as well as the need to supplement the medical equipment.

\section{SUMMARY}

The collection and analysis of data in the above work will expand the range of knowledge of medical rescuers from the area of tactical medicine. It will allow to provide first aid more effectively, especially for those with multi-organ injuries with coexisting massive haemorrhages.

The paramedic operating in the emergency medical system operates in the safe zone with the 
equipment in emergency backpacks, along with an ambulance and entities supporting the State Medical Rescue system. The victim is to receive full assistance according to current standards. The patient is to have all the tests done to confirm or rule out life-threatening injuries. Evacuation to the hospital takes place, if the situation requires, using equipment to fully immobilize the spine. Acting in combat conditions, a paramedic in a dangerous zone provides assistance to an injured person in the field of authorship or performs only simple activities to protect the basic life functions of the victim. It is only in a potentially safe zone that he or she uses emergency equipment stored in a rescue pack or a personal first aid kit. Evacuation of the victim takes place on a stretcher, which does not fully protect the victim with spinal injury.

The possibilities of using equipment in tactical medicine are very limited due to the possibility of evacuation. The rescuer usually works alone until the rescue helicopter arrives. It can, therefore, be based on rescue equipment that is able to transport itself. The characteristics of injuries on the battlefield mainly include heavy bleeding wounds with amputations and chest injuries. The main equipment of emergency kits is based on the possibility of supplying the above-mentioned injuries. The diversity and innovativeness of the dressings allow for plenty of life-threatening haemorrhages to be blocked in a very effective way. The implementation of such equipment for medical emergency teams operating under the PRM system would significantly increase the effectiveness of the activities carried out by rescuers in the scope of stopping massive haemorrhages.

\section{REFERENCES}

1. Ustawa z dnia 6.09.2006 r. O Państwowym Ratownictwie Medycznym.

2. Chomoncik M, Nitecki J, Poparda W. KPP w KSRG. PZWL, Warszawa 2018.

3. Jakubaszko J. Ratownik medyczny. Górnicki Wydawnictwo Medyczne, Wroctaw 2010.
4. Wypyszewska J, Kopański Z, Brukwicka I, et al. Badanie urazowe w Ratownictwie Medycznym i Ratownictwie Taktycznym. Journal of Clinical Healthcare. 2016(2): 10-19.

5. Emory J, Alson RL. International Trauma Life Support, ratownictwo przedszpitalne w urazach. Medycyna Praktyczna, Kraków 2017.

6. Kopta A. Kwalifikowana pierwsza pomoc. PZW, Warszawa 2016.

7. Dąbrowski M, Sanak T, Kluj P, et al. Specyfika udzielania pierwszej pomocy medycznej w warunkach bojowych w środowisku taktycznym na bazie standardu TCCC Część I. Przyczyny zgonów oraz odmienności w postępowaniu z poszkodowanym w warunkach bojowych w środowisku taktycznym na bazie standardu TCCC. Anestezjologia i Ratownictwo. 2013(7): 226-232.

8. Wypyszewska J, Kopański Z, Brukwicka I, et al. Epidemiologia urazówi zgonów na polu walki oraz historia powstania wytycznych TCCC. Journal of Clinical Healthcare. 2016(2): 1-5.

9. Sanak T, Dąbrowski M, Kluj P, et al. Specyfika udzielania pierwszej pomocy medycznej poszkodowanemu w warunkach bojowych w środowisku taktycznym na bazie standardu TCCC Częśćll. Zapewnienie hemostazy miejscowej podczas wykonywania zabiegów ratowniczych w fazie taktyczno-bojowej opieki nad poszkodowanym na bazie standardu TCCC. Anestezjologia i Ratownictwo. 2013(7): 94-103.

10. Podlasin A. Taktyczne ratownictwo medyczne. PZWL, Warszawa 2015.

11. Stankiewicz G, Milewski R. Ewakuacja medyczna MEDEVAC. Zeszyty Naukowe / Wyższa Szkoła Oficerska Wojsk Lądowych im. gen. T. Kościuszki. 2008(3): 20-31.

12. Chomoncik M. Ratownictwo medyczne w krajowym systemie ratowniczo-gaśniczym. Część l, Bezpieczeństwo i Technika Pożarnicza. 2019; 1: 131-152.

13. Sip M, Dąbrowski M, Sanak T, et al. Specyfika udzielania pierwszej pomocy medycznej w warunkach bojowych w środowisku taktycznym na bazie standardu TCCC. Część VI. Zestawy medyczne jako element wyposażenia medycznegoi zabezpieczenia indywidualnego żołnierzy Polskich Sił Zbrojnych. Anestezjologia i Ratownictwo. 2013(7): 354-367.

14. Karwin K. Ocena chorych po urazach wielonarządowych leczonych w szpitalnym oddziale ratunkowym. Polski Merkuliusz Lekarski. 2009(27): 160-296.

15. Wypyszewska J, Kopański Z, Brukwicka I, et al. Charakterystyka postępowania ratownika medycznego i ratownika taktycznego $z$ chorym, który doznał urazu. Journal of Clinical Healthcare . 2016(2): 6-9.

16. https://fia.com.pl/meldunek-medevac/ (26.10.2019). 